\title{
The EFFECTS OF PARTISAN ALIGNMENT ON THE ALLOCATION OF INTERGOVERNMENTAL TRANSFERS. DIFFERENCES-IN-DIFFERENCES ESTIMATES FOR SPAIN
}

\author{
ALBERT SOLÉ-OlLÉ \\ PILAR SORRIBAS-NAVARRO \\ CESIFO WORKING PAPER NO. 1855 \\ CATEGORY 1: PuBlic FinANCE \\ NOVEMBER 2006 \\ An electronic version of the paper may be downloaded \\ - from the SSRN website: \\ www.SSRN.com \\ - from the RePEc website: \\ Www.RePEc.org \\ - from the CESifo website: \\ www.CESifo-group.de
}




\title{
The EFFECTS OF PARTISAN ALIGNMENT ON THE ALLOCATION OF INTERGOVERNMENTAL TRANSFERS. DIFFERENCES-IN-DIFFERENCES ESTIMATES FOR SPAIN
}

\begin{abstract}
In this paper we test the hypothesis that municipalities aligned with upper-tier grantor governments (i.e., controlled by the same party) will receive more grants than those that are unaligned. We use a rich Spanish database, which provides information on grants received by nearly 900 municipalities during the period 1993-2003 from three different upper-tier governments (i.e., Central, Regional and Upper-local). Since three elections were held at each tier during this period, we have enough within-municipality variation in partisan alignment to provide differences-in-differences estimates of the effects of alignment on the amount of grants coming from each source. Moreover, the fact that a municipality may simultaneously receive grants from aligned and unaligned grantors allows us to use a tripledifferences estimator, which consists of estimating the effects of changing alignment status on the change in grants coming from the aligned grantors relative to the change in grants coming from the unaligned ones. The results suggest that partisan alignment has a sizeable positive effect on the amount of grants received by municipalities.
\end{abstract}

JEL Code: C72, D72.

Keywords: grant allocation, alignment, electoral competition.

\author{
Albert Solé-Ollé \\ Faculty of Economic Sciences \\ University of Barcelona \\ Avda. Diagonal 690, torre 4, planta 2 \\ 08031 Barcelona \\ Spain \\ asole@ub.edu
}

\author{
Pilar Sorribas-Navarro \\ Faculty of Economic Sciences \\ University of Barcelona \\ Avda. Diagonal 690, torre 4, planta 2 \\ 08031 Barcelona \\ Spain \\ psorribas@ub.edu
}

We acknowledge helpful comments from the participants in the CESifo-IFIR Workshop "New Directions in Fiscal Federalism", Kentucky 14-15th September 2006. This paper has benefited from financial support given under SEC2003-01388 (Spanish Ministry of Education and Science) and project 2005 SGR 000285 (the Generalitat of Catalonia). 


\section{Introduction}

The traditional literature on fiscal federalism justifies the use of intergovernmental transfers on the grounds of efficiency and equity (Musgrave, 1959; Oates, 1972). According to this view, grants should be used to foster spending in spillover-generating services, to reduce the use of inefficient local taxes (Dahlby and Wilson, 1994) or to guarantee similar access to essential public services across the country (Buchanan, 1950). However, many scholars have recognised that what grantor governments 'ought to do' does not help much when explaining what they 'actually do'. For example, Inman (1988) showed that the pattern of allocation of federal grants to the states in the US does not seem consistent with these normative prescriptions.

Recently, many papers have appeared with the purpose of testing several hypotheses regarding the effects of political incentives on the allocation of grants. Some of these hypotheses are derived from electoral competition models. For example, according to Lindbeck and Weibull (1987) and Dixit and Londregan (1998), upper-layer governments should allocate more grants to states with a high proportion of voters who are not specifically attached to any of the parties (the so-called 'swing voters'). The papers by Case (2001), Strömberg (2002), Johansson (2003) and Dahlberg and Johansson (2004) provide empirical evidence on the validity of this hypothesis. Some of these papers try to test this hypothesis against an alternative one (derived from Cox and McCubbins, 1986) that posits that, if politicians are risk averse, funds will be allocated to states where voters are clearly attached to the incumbent party (the 'core supporters'). The results in Dahlberg and Johansson (2004), and Castells and Solé-Ollé (2005) suggest that the evidence in favour of this hypothesis is not compelling, although, as Rodden and Wilkinson (2004) suggest, the task of separating the 'swing voter' and 'core supporter' hypotheses is not easy.

However, these approaches fail to answer a fundamental question: why should an upper-tier of government have an interest in delivering transfers to unaligned governments (i.e., controlled by opposition parties), which will surely try to use these funds to advance its electoral prospects (and, therefore, to harm those of the grantor government)? Of course, one may argue that these grants are generally earmarked for specific purposes and that the grantor invests in making clear to the citizens where the monies come from (e.g., by compulsory use of placards stating who the financial backer of the programme is). 
Nonetheless, the crucial point here is that, even if the grantee can claim some small proportion of the credit gained from the grant, the grantor will still find it less profitable to allocate funds to unaligned than to aligned governments (Dasgupta et al., 2004). This suggests that local governments that are aligned with upper-tier grantor governments will receive more grants than those that are unaligned. Several papers ${ }^{1}$ have tested this hypothesis, with most of them confirming that aligned states receive more funds than the unaligned ones. A common problem that can be found in most of these empirical exercises is the fact that they consider periods of unchanged partisan control at the upper layer of government (e.g. Grossman, 1994; Levitt and Snyder, 1995). This characteristic casts some doubt on the validity of the results, since the variable that measures alignment may be picking up other factors influencing the allocation of grants (e.g., greater needs in poor states controlled by the US Democratic Party).

In this paper we test the alignment hypothesis with a rich Spanish database, which provides information on grants received by nearly 900 municipalities during the period 1992-2003 from three different upper-tier governments (Central, Regional and Upperlocal). This database helps us to overcome data quality problems encountered by other authors in trying to test the alignment hypothesis. Firstly, in our database, there is crosssection variation in the partisan control in two of the upper-layer governments (Regional and Upper-local). Secondly, since three elections were held at each tier during this period, we have enough within-municipality variation in partisan alignment (due to changes in partisan control at all layers of government) to provide differences-in-differences estimates of the effect of alignment on the amount of grants coming from each source. The fact that a municipality may simultaneously receive grants from aligned and unaligned grantors allows us to use a triple-differences estimator, which consists of estimating the effects of changing alignment status on the change in grants coming from aligned grantors relative to the change in grants coming from unaligned ones. This estimator is more robust to the exclusion from the equation of economic and political determinants of the grants allocated by each upper-tier. The results suggest that partisan alignment has a sizeable effect on the amount of grants received by municipalities.

\footnotetext{
${ }^{1}$ See, e.g., Grossman (1994) and Levitt and Snyder (1995) for the USA, Worthington and Dollery (1998) for Australia, and Dasgupta et al. (2004) and Khemani (2003) for India.
} 
The paper is organised as follows. In the second section we provide a simple electoral competition model that accounts for the different incentives that grantors have regarding aligned and unaligned local governments. The third section performs the empirical analysis. In this section we explain the different estimation procedures that we have been able to implement, the features of our database and the way we measure grants and alignment. This section ends with the presentation of the results. The fourth section sets out our conclusions.

\section{Theoretical model}

In this section we develop an electoral competition model with the only aim of providing a simple framework for our empirical exercise. The purpose of the model is to account for the incentives that grantors have regarding aligned vs. unaligned governments. The section is organised as follows. We first describe the basic setup of the model: the layers of government and parties analysed. Then we describe how a voter decides his vote, depending on the alignment between governments at different tiers. Then we describe both the objective of the upper layers of government (in terms of parties) and the results of the electoral game in terms of grants allocated to each local government.

\section{Basic setup}

In our model we have two upper-tier governments, each with a jurisdiction covering the entire country, and $n+m$ municipalities. We will call the first tier $U$ (Upper-local) and the second one $R$ (Regional). For illustrative purposes, we assume that each upper-tier government is controlled by a different party: the $U$ government by the left-wing party $(l)$ and the $R$ government by the right-wing one $(r) . n$ municipalities are controlled by the $r$ party and $m$ by the $l$ party. The parties $r$ and $l$ use the financial resources available at the layers of government they control to advance their electoral prospects ${ }^{2}$. Although each party controls a different government tier, and different elections are held at each tier, we analyse a game in which they are competing in the same electoral race, without specifying which specific election we are talking about. We are, in fact, assuming that the politicians at all levels have

\footnotetext{
${ }^{2}$ Note that the parties do not compete by promising transfer allocations as in more traditional, spatial voting settings (see, e.g. Lindbeck and Weibull, 1987), but by distributing real funds. In this sense, this setting more closely resembles models explaining the allocation of campaign efforts among districts (see, e.g., Snyder, 1989, and Strömberg, 2002).
} 
an interest not only in winning the elections held at their levels, but also in advancing the prospects of the party in general. This may happen if campaigns are highly centralised, if the electoral results of a party in a given election and jurisdiction are influenced by the results obtained in other contests, or if winning elections helps the party in rewarding its supporters through the allocation of posts.

\section{Voting behaviour}

Voters cast their vote on the basis of two criteria: (i) the welfare generated by grants, $u_{j}\left(g_{j}\right)$, with $u_{j}^{\prime}\left(g_{j}\right)>0$ and $u_{j}^{\prime \prime}\left(g_{j}\right)<0$, and where $g_{j}=g_{j}^{U}+g_{j}^{R}$ are per capita grants in municipality $j$, coming from $U$ and $R$, respectively; and (ii) ideology. We define $X_{i}$ as the ideological bias of voter $i$ in favour of $l$; and $\Phi_{j}(X)$ is a municipality-specific distribution of $X$, with $\phi_{j}(X)=\partial \Phi_{j}(X) / \partial X$, which is common knowledge. $\Phi_{j}(X)$ is assumed to be symmetric and single-picked. There is a stochastic component in voting behaviour which is a popularity shock, $\delta_{j}$, in favour or against the party in the $R$ and $U$ governments. We assume that voter $i$ votes for party $r$ if $u_{j}\left(g_{j}^{R}\right)-u_{j}\left(g_{j}^{U}\right) \geq X_{i}{ }^{3}$.

Now we assume that the voting decision of voter $i$ depends on the alignment status of his local government. Following Dasgupta et al. (2004), we define $\theta$ as the proportion of utility from grants attributed to the local government, and $(1-\theta)$ as the proportion of utility from grants attributed to the grantor upper layer of government. If both layers are controlled by the same party, then all the utility from grants is captured by this party. If control is split between the two parties, then utility from grants must be shared. Thus, if the incumbent party at municipality $j$ is $r$, i.e. $j$ is aligned with $R$, voter $i$ votes for party $r$ if:

$$
\underbrace{u_{j}\left(g_{j}^{R}\right)+\theta u_{j}\left(g_{j}^{U}\right)+\delta_{j}}_{\text {utility captured by } r}>X_{i}+\underbrace{(1-\theta) u_{j}\left(g_{j}^{U}\right)}_{\text {utility captured by } l}
$$

or,

$$
X^{a}=u_{j}\left(g_{j}^{R}\right)-(1-2 \theta) u_{j}\left(g_{j}^{U}\right)+\delta_{j}>X_{i}
$$

That is, expression (2a) says that if a municipality is aligned with $R$, all the utility coming from grants allocated by $R$ is captured by the party $r$ but, since the municipality is not aligned

\footnotetext{
${ }^{3}$ The voter will vote for $r$ if the welfare gain obtained from $r$ during the last term of office relative to the gain obtained from $l$ is higher than the ideological bias in favour of $l: \Delta u_{j}^{r}-\Delta u_{j}^{l} \geq X_{i}$. This welfare gain is hypothetical and should be interpreted as the increase in welfare caused by grants coming from the government controlled by party $r$ compared to a hypothetical situation in which all the grants came from a government controlled by the other party. Only in this case does $\Delta u_{j}^{r}$ - $\Delta u_{j}^{l}$ reduce to $u_{j}\left(g_{j}^{R}\right)$ $u_{j}\left(g_{j}^{U}\right)$.
} 
with $U$, also a proportion $\theta$ of the grants allocated by $U$ is captured by party $r$. Similarly, if the incumbent party at municipality $j$ is $l$, i.e. municipality $j$ is unaligned with $R$, voter $i$ votes for party $r$ if:

or,

$$
\underbrace{(1-\theta) u_{j}\left(g_{j}^{R}\right)+\delta_{j}}_{\text {utility captured by } r} \geq X_{i}+\underbrace{u_{j}\left(g_{j}^{U}\right)+\theta u_{j}\left(g_{j}^{R}\right)}_{\text {utility captured by } l}
$$

$$
X^{u}=(1-2 \theta) u_{j}\left(g_{j}^{R}\right)-u_{j}\left(g_{j}^{U}\right)+\delta_{j}>X_{i}
$$

Party behaviour

The objective of each party is to maximize the expected number of votes assuming the decision of the other party is fixed (i.e., Nash behavior) and subject to a fixed budget constraint. For example, in the case of party $r$, this can be expressed as:

$$
\underset{g_{1} \ldots g_{m}}{\operatorname{Max}} \sum_{j=1}^{n} N_{j} \Phi_{j}\left(X^{a}\right)+\sum_{k=1}^{m} N_{k} \Phi_{k}\left(X^{u}\right) \quad \text { s.t.: } \quad \sum_{j=1}^{n} N_{j} g_{j}^{R}+\sum_{k=1}^{m} N_{j} g_{j}^{R}=G^{R}
$$

where $N_{j}$ is the population of municipality $j$, and $G^{R}$ and $G^{U}$ are the exogenous amounts of resources available to the $R$ and $U$ upper-layer governments. The problem of party $l$ can be stated in similar terms.

\section{Solution}

The FOCs for the party $r$ (upper layer of governments $R$ ) are :

aligned $(j=1, . ., n)$ :

unaligned $(k=1, . ., m)$ :

$$
\begin{gathered}
\phi_{j}\left(X^{a}\right) u_{j}^{\prime}\left(g_{j}^{R}\right)=\lambda^{R} \\
\phi_{k}\left(X^{u}\right) u_{k}^{\prime}\left(g_{k}^{R}\right)(1-2 \theta)=\lambda^{R}
\end{gathered}
$$

The FOCs for the party $l$ (upper layer of governments $U$ ) are :

unaligned $(j=1, . ., n)$ :

$$
\begin{gathered}
\phi_{j}\left(X^{a}\right) u_{j}^{\prime}\left(g_{j}^{U}\right)(1-2 \theta)=\lambda^{U} \\
\phi_{k}\left(X^{u}\right) u_{k}^{\prime}\left(g_{k}^{U}\right)=\lambda^{U}
\end{gathered}
$$

The FOCs state that the marginal benefit of allocating grants to municipality $j$ should be equal to the marginal cost of revenues. The marginal benefit is the product of three terms: (i) the density at the 'cut-point', or the proportion of 'swing voters'; (ii) the marginal utility of grants; and (iii) in the case of unaligned governments, the transfer of utility to the other party due to unalignment, $(1-2 \theta)$. This term is lower than one, reducing the marginal benefit of allocating grants to this municipality. 
Note that if $\theta>0.5$ (i.e., if the grantee captures more benefits than the grantor), the marginal utility of grants becomes negative. In this case we will have a corner solution with zero grants allocated to unaligned municipalities. However, this seems to be an extreme case for at least two reasons. Firstly, if parties were not merely office-motivated but also pursuing efficiency and/or equity objectives, the marginal benefit of grants in (5) would include an additional term, making the corner solution more difficult (see, e.g, Dasgupta et al., 2004). Secondly, there must be an upper bound on the utility derived from grants that spills over to any opposition party. We assume that $\theta<0.5$, meaning that although the grantee may obtain substantial utility from projects funded by the grantor, the grantee never obtains more utility than the grantor.

\section{Effect of alignment on grant allocation}

The analysis of the FOCs allows us to make two different predictions about the effects of alignment status on the amount of grants allocated. The first prediction states that a grantor government allocates more funds to aligned municipalities than to unaligned ones. This hypothesis is obtained by comparing the two FOCs for the same grantor (either $R$ or $U$ ). Look, for example, at the ratio between (5a) and (5b):

$$
\frac{\phi_{j}\left(X^{a}\right)}{\phi_{k}\left(X^{u}\right)} \frac{u_{j}^{\prime}\left(g_{j}^{R}\right)}{u_{k}^{\prime}\left(g_{k}^{R}\right)(1-2 \theta)}=1
$$

To isolate the effects of alignment from other influences, assume that $\Phi_{j}=\Phi_{k}=\Phi$ and $u_{j}=u_{k}=u$, meaning that both the shape of the distribution function and the utility function are the same in municipalities $j$ and $k$. Let's also assume, for the moment, that the popularity shock is zero (i.e., $\delta_{j}=\delta_{k}=0$ ). These assumptions imply that the density at the cut-point is equal in both municipalities; thus, the ratio between the two densities is equal to one. In this scenario, given that $\theta<0.5$, the denominator of the LHS of (6) is multiplied by a factor, (1-2 $\theta$ ), lower than one. Since $u^{\prime}>0$ and $u^{\prime \prime}<0$, then $g_{j}^{R}>g_{k}^{R}$ is needed to rebalance expression (6). Hence, in this case the $R$ upper-tier of government (controlled by $r$ ) clearly gives more monies to the $j$ municipality (aligned with $R$ ) than to the $k$ one (unaligned). In the case where the party governing $R$ receives a negative popularity shock (i.e. $\delta_{j}=\delta_{k}<0$ ), the density at the 
cut-point is higher for the aligned municipality than for the unaligned one ${ }^{4}$, so a further increase of $g_{j}^{R}$ (decrease of $g_{k}^{R}$ ) is needed to rebalance expression (6), reinforcing the previous result. In contrast, when the party governing $R$ receives a positive popularity shock, then the density at the cut-point is higher for the unaligned municipality. But in this case, the second effect could offset the former one, precluding any clear conclusion about the effect of alignment on grants. However, the magnitude of this second effect depends on the curvature of the density function: specifically, in this case, $g_{j}^{R}>g_{k}^{R}$ if $(1-2 \theta) \phi_{k}\left(X^{u}\right)>\phi_{j}\left(X^{a}\right)$.

When $\Phi_{j} \neq \Phi_{k}$ and/or $u_{j} \neq u_{k}$, the alignment effect may not hold because a municipality with a higher proportion of swing voters or with a higher spending valuation may receive more grants even if it is unaligned with the grantor. However, controlling for these variables, aligned municipalities could also receive more grants from a given grantor than unaligned ones could. Assuming that the vote-distribution functions for $j$ and $k$ are uniform on the intervals $\left[-1 / 2 \psi_{j}, 1 / 2 \psi_{j}\right]$ and $\left[-1 / 2 \psi_{k}, 1 / 2 \psi_{k}\right]$, respectively, this result can be illustrated by the following specific utility function:

$$
u_{j}\left(g_{j}\right)=\kappa+\frac{b_{j}}{1-1 / \alpha}\left(g_{j}\right)^{1-1 / \alpha}
$$

where $\kappa$ and $\alpha$ are constants, with the latter measuring the concavity of the utility function; and $b_{j}$ is a parameter indicating that spending is more valuable to voters in some places. Substituting this function in (5a) and (5b), we obtain:

$$
\frac{g_{j}^{R}}{g_{k}^{R}}=\left(\frac{\psi_{j}}{\psi_{k}} \frac{b_{j}}{b_{k}(1-2 \theta)}\right)^{\alpha}
$$

Whenever $\left(\psi_{j} b_{j}\right)^{\alpha}>\left(\psi_{k} b_{k}(1-2 \theta)\right)^{\alpha}$, then $g_{j}^{R}>g_{k}^{R}$. That is, the aligned municipality will receive more grants than the unaligned one.

The second prediction says that a municipality receives more funds from an aligned grantor than from an unaligned one. This hypothesis is obtained by comparing the FOCs for the same municipality ( $j$ or $k$ ). Look, for example, at the ratio between (5a) and (5c):

$$
\frac{u_{j}^{\prime}\left(g_{j}^{R}\right)}{u_{j}^{\prime}\left(g_{j}^{U}\right)(1-2 \theta)}=\frac{\lambda^{R}}{\lambda^{U}}
$$

\footnotetext{
${ }^{4}$ In this case both cut-points are displaced to the left of the distribution function by the same magnitude. Since the departure point for $k, X_{k}$, is negative, the density at the cut-point is lower in $k$ than in $j$, and the ratio is higher than one.
} 
Let's assume that $\lambda^{R}=\lambda^{U}$. Since $\theta<0.5$, the denominator of the LHS of (9) is multiplied by a factor that is lower than one. Given that $u_{j}^{\prime}>0$ and $u_{j}^{\prime \prime}<0$, then $g_{j}^{R}>g_{j}^{U}$ is needed in order to rebalance expression (9). So, municipality $j$ receives more monies from the $R$ grantor (aligned with municipality $j$ ) than from the $U$ grantor (unaligned with $j$ ). When $\lambda^{R} \neq \lambda^{U}$, this result may not hold since the grantor with more resources may spend more in every municipality (aligned or unaligned) independently of their alignment. This result can be illustrated by using the same utility function as above. Substituting this function in (5a) and (5c), and summing over all municipalities and using the budget constraint, we obtain:

$$
\frac{g_{j}^{R}}{g_{j}^{U}}=\left(\frac{G^{R}}{G^{U}} \frac{1}{1-2 \theta}\right)^{\alpha}
$$

where $G^{R} / G^{U}$ is the ratio between the exogenous amount of resources available to the grantors $R$ and $U$, respectively. Controlling for the amount of resources at the disposal of $R$ and $U$, if $\left(G^{R}\right)^{\alpha}>\left(G^{U}(1-2 \theta)\right)^{\alpha}$, then an aligned upper-tier government still allocates more grants to a given municipality than an unaligned one.

\section{Empirical analysis}

\subsection{Background information on Spain}

Layers of government. Spain is a fiscally decentralized country with three layers of government: Central, Regional, and Local. There are seventeen regional governments, called Autonomous Communities (AC), which have quite important spending responsibilities, for example, in the provision of health care, education and welfare. Each AC is composed of one or more provinces. In the ACs with more than one province, there also exists an upper-tier of local government, called Diputación. This upper-tier of local government has fewer spending responsibilities than the municipalities, which are the main players in the local public sector. One of its pertinent tasks is allocating grants for capital infrastructure to the municipalities ${ }^{5}$.

Spain has over eight thousand municipalities, although most are quite small. Municipalities are multi-purpose governments, with major expenditure categories corresponding to the traditional responsibilities assigned to the local public sector (environmental services, urban planning, public transport, welfare, etc.), with the exception of

\footnotetext{
${ }^{5}$ In ACs with only one province (there are six ACs of this kind), there is no Diputación, and its responsibilities are assumed by the regional government.
} 
education, which is a responsibility of the regional government. Current spending is financed out of their own revenues (approx. 2/3) and unconditional grants (approx. 1/3), which are allocated according to a formula that hinders their use for pork-barrel politics. However, the funding of capital spending depends heavily on grants: in 2003, capital grants represented $13 \%$ of non-financial revenues and $44 \%$ of capital spending. These grants come from the three aforementioned upper layers of government: Central (15\%), Regional (45\%) and Upper-local (21\%) ${ }^{6}$. Most of the grants take the form of 'project grants': there is an open call at regular intervals (usually yearly) and a municipality must apply by submitting several infrastructure projects, which are evaluated against criteria that have been previously establish-ed (probably published in the call) but are subject to the interpretation of the grantor. Therefore, the degree to which these grants are politically discretionary should be qualified as high.

Elections and parties. General elections are regularly held at four-year intervals, although they can be called before a term of office expires. Municipal and regional elections are held regularly every four years and on the same day in twelve out of seventeen ACs. In the period analyzed, they were called one or two years before general elections. In the other ACs, elections were called before an end of term and, therefore, were held on a different day.

In the elections to central and regional legislative bodies, the provinces constitute the electoral districts, a differing number of representatives are elected in each province depending on its population, candidates appear on the parties' closed lists, and the d'Hondt formula, with threshold, is used to translate votes into representatives (Colomer, 1995). Therefore, the system is not entirely proportional and, in fact, it is much easier to win a seat in some provinces (the rural ones) than in others. The system allows a certain degree of plurality in parliament, especially in the case of regional parties whose vote is concentrated in a few districts. Because of the closed-list system, parties are highly disciplined, both inside the legislatures and (to a minor extent) across layers of government. Since the party has a great influence on the future prospects of politicians (through the allocation of posts and of places in the lists), politicians are at least as loyal to the party as they are to their constituency.

In municipal elections there are also closed lists, the number of city councillors depends on population, and the d'Hondt rule is again used, but in this case there is a single district. As

\footnotetext{
${ }^{6}$ The remaining $18 \%$ corresponds to other sources (e.g., the EU) or to unspecified grants.
} 
Colomer (1995) states: “these rules provide incentives for sincere voting and promote a high degree of pluralism in city councils”. As a result, there is a high proportion of coalition governments. For example, in the 1996-99 term, 43.3\% of municipalities where governed by coalitions (Solé-Ollé, 2006). Most municipal candidates are aligned along national or regional party lines. The local political system is seen as a first step in the process of recruitment into the regional and national political elite (Magre, 1999). There are no specific elections to the assembly of the upper-tiers of local governments; the representatives of Diputaciones are elected as a product of the results of municipal elections. The votes for each party are aggregated across municipalities and are translated into representatives, again using the d'Hondt formula. These upper-tiers of government have been criticized on the grounds of reduced electoral accountability. With few clear-cut responsibilities and no need to go to the polls, politicians controlling this layer of government can use grants to foster party prospects at the next municipal election.

The features of the Spanish electoral and party system described above mean that the elections held at each layer of government are not entirely independent of the national political situation. In fact, parties have a strong vested interest in the results of regional and municipal elections. Since these contests generally happen one or two years before general elections, they provide an excellent opportunity to test the real prospects of the party ${ }^{7}$. Therefore, although most campaign efforts are regional or local in scope, the parties do design a centralized strategy for these contests. This strategy includes statements regarding which regions and municipalities deserve disproportionate campaign efforts ${ }^{8}$, either because the perceived electoral margin is narrow or because the region or city is seen as having special significance in the eyes of voters (e.g., big cities). In the Spanish context, it is therefore natural to expect that just before an election, a party will use the various posts it controls at different layers of government to allocate grants to pursue its electoral objectives. The high

\footnotetext{
${ }^{7}$ This is due to the fact that national political shocks do affect the results of these lower-tier elections. For evidence of this effect in Spain and in other countries, see e.g. Solé-Ollé and Bosch (2005), and Rodden et al. (2005), respectively. In fact, local electoral results are seen as predictors of party prospects for the next general election.

${ }^{8}$ One year before the future May 2007 municipal elections, the newspaper El País published a report on the prospects for this contest under the title, "PSOE and PP open the battle town by town", which identified the regions and municipalities where each party will concentrate its efforts (source: El País, 23th April 2006, p. 26: “PSOE y PP abren la batalla pueblo a pueblo").
} 
degree of partisan control exercised both within and across layers of government facilitates the use of resources coming from different posts for the fulfilment of party interests.

\subsection{Econometric framework}

Our econometric framework is built upon the results from the theoretical section. Since the Spanish case described above provides us with three upper-tier grantor governments (Central: $C$, Regional: $R$, and Upper-local: $U$ ) we can posit three equations, one for the grants allocated by each of these tiers:

$$
\begin{aligned}
& g_{j, \ell, t}^{C}=\beta_{1} a_{j, t}^{C}+\beta_{2} \phi_{j, t}+\beta_{3} b_{j, t}+f_{j}+f_{\ell, t}^{C}+\varepsilon_{j, t}^{C} \\
& g_{j, \ell, t}^{R}=\beta_{1} a_{j, t}^{R}+\beta_{2} \phi_{j, t}+\beta_{3} b_{j, t}+f_{j}+f_{\ell, t}^{R}+\varepsilon_{j, t}^{R} \\
& g_{j, \ell, t}^{U}=\beta_{1} a_{j, t}^{U}+\beta_{2} \phi_{j, t}+\beta_{3} b_{j, t}+f_{j}+f_{\ell, t}^{U}+\varepsilon_{j, t}^{U}
\end{aligned}
$$

where $g_{j, \ell, t}^{C}, g_{j, \ell, t}^{R}$ and $g_{j, \ell, t}^{U}$ are per capita grants allocated by $C, R$ and $U$ grantors, respectively, to municipality $j$, located in (national and regional) electoral district $\ell$, for the municipal term of office $t$. The effects of alignment are picked up by the dummies $a_{j, t}^{C}, a_{j, t}^{R}$ and $a_{j, t}^{U}$, which are equal to one if municipality $j$ is aligned with the $C, R$ or $U$ grantor for the term of office $t$. The terms $\phi_{j, t}$ and $b_{j, t}$ measure the effects of 'swing voters' (i.e., cut-point density) and needs/preferences (i.e., marginal utility of spending) respectively. We provide more details regarding how we measure these variables in the next section. In any case, since these effects will be difficult to measure, we should account for omitted political and economic influences through the inclusion of municipal effects, $f_{j}$. Moreover, we include electoral district $\times$ term-of-office effects, $f_{\ell, t}^{C}, f_{\ell, t}^{R}$ and $f_{\ell, t}^{U}$. These effects account for the different amounts of resources available to different grantors in different terms of office, and for potential omitted political variables that change from district to district and from one electoral contest to the next, but which are constant across municipalities of the same district ${ }^{9}$. Finally, $\varepsilon_{j, t}^{C}, \varepsilon_{j, t}^{R}$ and $\varepsilon_{j, t}^{U}$ are well-behaved error terms.

The database (explained below) allows us to exploit the cross-section and time-series variation across different upper-layers of grantor governments to deal with potential omittedvariable problems and identify the effects of alignment on grant allocation. To illustrate the

\footnotetext{
${ }^{9}$ The votes obtained in a municipality may be more valuable if the municipality is located in an electoral district where less votes are needed to gain a representative (because of lack of proportionality) (see, eg, Castells and Solé-Ollé, 2005, for evidence).
} 
advantages of our methodology, it is convenient to explain the four different procedures we use, step by step, from simplest to most complex. The first and third procedures are based on the proposition that a grantor will give more monies to aligned municipalities than to unaligned ones (expressions (6) and (8)). The second and fourth procedures are based on the proposition that a municipality will receive more monies from aligned grantors than from unaligned ones (expressions (9) and (10)). The first procedure, called cross-section, consists of using only the cross-section variation in the grants allocated by each grantor separately. Studies that do not have access to panel data or do not have information regarding different grantor governments must resort to this procedure. Let's assume, for example, that we only have information on the grants distributed by $R$ during one term of office:

$$
g_{j, \ell}^{R}=\beta_{1} a_{j}^{R}+\beta_{2} \phi_{j}+\beta_{3} b_{j}+f_{\ell}^{R}+\eta_{j}^{R}
$$

where $\eta_{j}^{R}=f_{j}+\varepsilon_{j}^{R}$.

If $\operatorname{cov}\left(a_{j}^{R}, \varepsilon_{j}^{R}\right)=0$, we can obtain an unbiased estimate of $\beta_{1}$ by controlling appropriately for $\phi_{j}$ and $b_{j}$ and by including a full set of electoral district dummies, $f_{\ell}^{R}$. In practice, however, it is not so straightforward. For example, if there is only one upper-layer government covering all the jurisdiction of the country (as often occurs in empirical analyses, e.g., Grossman, 1994), then $a_{j}^{R}$ will not only measure alignment but also differences in party control among municipalities. And, since party control is usually correlated with omitted socio-demographic variables (e.g., the left generally controls 'poor' municipalities, at least in Spain), the parameter $\beta_{1}$ will be biased unless the list of variables included in $b_{j}$ is exhaustive (i.e., $\left.\operatorname{cov}\left(a_{j}^{R}, \varepsilon_{j}^{R}\right) \neq 0\right)$. Similarly, $a_{j}^{R}$ may be correlated with $\phi_{j}$ if, for example, left governments tend to win by slim margins while the electoral advantage of right governments is substantial (or vice versa). Thus, this procedure is far from perfect. Nevertheless, we use it in our empirical exercise for two different reasons: firstly, to demonstrate the differences between this procedure and alternative ones (see below); and secondly, because in two of our upper-layer governments, the country is divided into several jurisdictions, and not all of them are controlled by the same party, attenuating the first of the problems mentioned above.

The second procedure, called time differences-in-differences, consists of collecting data on the grants allocated by one grantor government in successive terms of office, to be able to estimate the effects of changes in alignment on changes in grants received. With this 
information we will able to estimate equations (11a) to (11c) after taking first differences. As an example, in the case of the $R$ government, we have:

$$
\Delta g_{j, t}^{R}=\beta_{1} \Delta a_{j, t}^{R}+\beta_{2} \Delta \phi_{j, t}+\beta_{3} \Delta b_{j, t}+f_{\ell, t}^{R}+\Delta \varepsilon_{j, t}^{R}
$$

where $\Delta$ indicates that the variable has been computed as the difference in the values between two consecutive terms of office, and $\beta_{1}$ is now the differences-in-differences estimator ${ }^{10}$. The main advantage of this procedure is the attenuation of the omitted-variable problem, especially in the case of needs variables $\left(b_{j}\right)$, since some of them could reasonably be considered fixed (e.g., land area and other physical characteristics). Some electoral features $\left(\phi_{j}\right)$ might also be quite stable; however, others may change from one term of office to the next, and this change might be correlated with changes in alignment status $\left(\Delta a_{j, t}^{R}\right)$. Moreover, in some samples, the change in alignment may stem solely from a change in control at the municipal level. This may happen if control at the grantor level remains stable. In such case, the second procedure retains some of the problems of the first one.

The third procedure, called grantor differences-in-differences, consists of using data on grants allocated to local governments by different upper-layer grantor governments in a given term. Subtracting expression (12) for two grantor governments, $R$ and $U$, we have:

$$
g_{j, \ell}^{R}-g_{j, \ell}^{U}=\beta_{1}\left(a_{j}^{R}-a_{j}^{U}\right)+f_{\ell}^{R U}+\eta_{j}^{R U}
$$

where $f_{\ell}^{R U}$ is a full set of electoral district dummies and $\eta_{j}^{R}=\left(f_{j}^{R}-f_{j}^{U}\right)+\left(\varepsilon_{j}^{R}-\varepsilon_{j}^{U}\right)$. The $\beta_{1}$ parameter is the differences-in-differences estimator, obtained by using the same local governments as a control group, but supposing that they are in a different situation (i.e., receiving grants from an upper-layer government controlled by a different party).

Since the grantor differences-in-differences estimator does not provide unbiased estimates of the alignment effect, we propose a fourth procedure, called triple-differences estimator, which uses panel data on grant allocation to local government by different upperlayer governments in successive terms of office. The expression using the $R$ and the $U$ upper layers of government is:

\footnotetext{
${ }^{10}$ In the differences-in-differences estimation, the standard errors are inconsistent if there is severe serial correlation. This is not so in our case, since none of the three characteristics that the literature points to as the source of this problem (a fairly long time series, a dependent variable that is highly positively correlated, and few changes in the control variable (alignment)) is present in our analysis; Bertrand et al. 2004). Thus, we will not make any correction on the standard errors obtained.
} 


$$
\Delta g_{j, \ell}^{R}-\Delta g_{j, \ell}^{U}=\beta_{1}\left(\Delta a_{j}^{R}-\Delta a_{j}^{U}\right)+f_{\ell}^{R U}+\Delta \varepsilon_{j}^{R U}
$$

In this case, the alignment effect is identified by a regression which uses as the dependent variable the difference between the grant increase (in two consecutive terms of office) of two grantor governments and, as explanatory variables, the change in alignment status vis-à-vis one grantor minus the change in alignment vis-à-vis the other. That is, if local government $j$ switches from $l$ to $r$ after an election, the increase in grants received from $R$ should be higher than the increase in grants received from $U$. This estimation should be more robust than the previous ones due to the omission of political and economic variables in the equation. Nonetheless, the good properties of this estimator depend on the validity of the assumption of equality of coefficients across equations, implicit in equations (11a) to (11c). There are some reasons to believe that this may not be the case. Firstly, as suggested by expression (10), the additional grants that a municipality may receive from an aligned grantor depend on the amount of resources distributed, so the $\beta_{1}$ coefficients should be allowed to differ between equations. Secondly, different grantors may subsidise different types of projects, so a given variable included in $b_{j}$ may be weighted differently by each of them. Thirdly, since we have more than two parties, it may happen that the density at the cut-point $\phi_{j}$ is no longer the same for all the parties. To account for these possible sources of bias, we include an additional set of controls in the estimation of equations (14) and (15). For example, the extended grantor differences-in-differences equation looks like:

$$
g_{j, \ell}^{R}-g_{j, \ell}^{U}=\beta_{1}^{R}\left(a_{j}^{R}-a_{j}^{U}\right)+\left(\beta_{1}^{R}-\beta_{1}^{U}\right) a_{j}^{U}+\beta_{2}\left(\phi_{j}^{R}-\phi_{j}^{U}\right)+\left(\beta_{3}^{R}-\beta_{3}^{U}\right) b_{j}+f_{\ell}^{R U}+\eta_{j}^{R U}
$$

The coefficient of $\left(a_{j}^{R}-a_{j}^{U}\right)$ expresses the effect of alignment on grants received from the $R$ grantor while the coefficient of $a_{j}^{U}$ allows us to test the equality of the coefficients of the two grantors. The triple-differences estimator is amended in a similar way with the inclusion of the same set of controls. After these modifications, the triple-differences estimator is expected to perform better than the other ones.

\subsection{Sample and data}

Selecting the sample. We estimate the effects of alignment on grant allocation, with data on Spanish municipalities. We use a rich database, which provides information on grants received by 869 local governments during the period 1993-2003, from three different uppertier governments (i.e., Central, Regional and Upper-local). The data comes from a survey on 
budget outlays conducted yearly by the Ministry of Economics and Finance. The starting number of municipalities is much bigger $(2,799)$, but lack of data or the desired breakdown has necessitated reduction in the size of the sample. In the case of grants coming from the $U$ government this number is further reduced to 755 , due to the already mentioned fact that there are no Diputaciones in ACs with only one province.

We estimate the effects of alignment for the three terms of office mentioned above. However, we use only the last two years of each term to perform our analysis. Thus, we set out to explain the effects of alignment on the overall amount of grants received in 1994-95 for the term 1991-95, in 1998-99 for the term 1996-99, and in 2002-03 for the term 2000-03. There are three reasons that justify this decision. The first one is the fact that it is quite difficult to identify alignment between layers of government given the different timing of general and (some) regional elections. Thus, the alternative procedure of aggregating grants over an entire local term of office would have encountered the problem of changing alignment in the middle of the period (since regional and general elections are held at some time between two local elections). The second reason is that by aggregating the grants variable over two years, we reduce the volatility of this variable. The third reason is that, as the political cycle literature has emphasised, the temptation to use public funds to buy votes increases as the next election approaches ${ }^{11}$.

Measuring grants. Our grants variables are capital grants (chapter 7 of the budget) coming from each upper layer of government $(C, R$ and $U)$. Grants are added up for the last two years of each term then divided by the population of the municipality at the beginning of these twoyear periods, using data from the National Institute of Statistics (INE). We have considered that grants received during the election year benefit the incumbent government and not the incoming one. We believe that this assumption is reasonable, given that municipal elections are generally held in the middle of the year (May or June) and that grantor governments usually exhaust their yearly grants budgets early, just before the next election.

Measuring alignment. The concept of alignment is straightforward in the case of singleparty governments. In this case, a municipality is said to be aligned with an upper-layer grantor government if the party controlling the government at both layers is the same.

\footnotetext{
${ }^{11}$ See, e.g., Castells and Solé-Ollé (2005) for evidence indicating that pork-barrel politics in Spain intensifies as the next election approaches.
} 
However, in Spain a large share of governments (at all layers) are coalitions. Coalitions make the definition of alignment between layers more difficult. A party at a given layer of government may play at least three different roles: i) the single party in government, ii) the main partner or leader of a coalition, and iii) a mere partner of the leading party in a coalition. Paired combinations of these roles between a municipality and a higher layer of government define nine different relationship types, which are illustrated in Table 1.

Table 1:

\begin{tabular}{|c|c|c|c|c|}
\hline & \multicolumn{4}{|c|}{ A typology of alignment status } \\
\hline \multirow{5}{*}{ 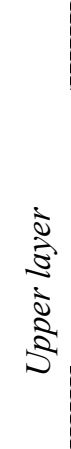 } & \multicolumn{4}{|c|}{ Municipality } \\
\hline & & $\begin{array}{c}\text { Single } \\
\text { party }\end{array}$ & Leader & Partner \\
\hline & $\begin{array}{l}\text { Single } \\
\text { party }\end{array}$ & $a$ & & \multirow{3}{*}{$c$} \\
\hline & Leader & & $b$ & \\
\hline & Partner & & & \\
\hline
\end{tabular}

The amount of grants transferred to municipalities belonging to each of these types depends on two different factors. Firstly, as it has been explained in the theoretical section, it depends on the credit lost by the grantor government. If both layers are controlled by the same single party, there is no credit loss, but if this party is the leader of a municipal coalition, part of the credit will flow to its local partner(s). If this party is only a partner at the municipal level, the party leading the municipal coalition may get a large share of the credit. These considerations do not seem to depend on the status of the upper layer, so grant levels should decrease as we move from left to the right in Table 1. Secondly, it depends on the ability of the upper layer of government to secure a large share of the funds available to be distributed. Of course, a single-party government is able to use the entire grants budget as it wishes, without having to share it with other parties. But we need to rely on coalition theory to answer which of the other two types is more able to obtain funds. Some papers suggest that a coalition leader or formateur (i.e., the party charged with the task of forming the coalition) is able to secure a larger share of benefits than other coalition members (Baron and Ferejohn, 1989). However, other papers suggest that the ability to obtain benefits for the party will be 
greater when it can pivot between alternative, minimum-winning coalitions (Schofield, 1976, Ansolabehere and Snyder, 2004; see Rodden and Wilkinson, 2004 for empirical evidence). This clearly means that strong coalition partners will receive more grants than weak ones. Nevertheless, it is not at all clear that strong partners will be able to control more funds than a coalition leader. Moreover, we have not been able to identify whether coalition partners are pivotal or not in all the cases, so our sample of Partners mixes both pivotal parties and weaker ones. Therefore, we still expect that coalition leaders are able to control more funds than coalition partners.

The use of such a high number of categories in the empirical analysis is not operative, since most of them are empty or have a very small share of municipalities. For this reason, we have decided to use only four groups (see Table 1), defined as follow: (a) Single party: the same party controls a single-party government at both layers; (b) Leader: a party which controls a single-party government at one layer and leads a coalition at the other layer; $(c)$ Municipal partner: a party belonging to the upper layer of government (either the single party, the leader of a coalition or a mere partner) and is merely a partner in a municipal coalition; and (d) Upper-layer partner: a party which is a partner at the upper layer and either the single party or the leader of a coalition at the municipal level. We expect to find the highest grants in ( $a$ ) because the effects of the loss of credit and of the capacity to secure funds go in the same direction. The lowest grants are expected in $(c)$, meaning that the loss of credit effect dominates. As we have said before, we expect more grants in $(b)$ than in $(d)$ since, given a similar ability to gain credit, single parties and coalition leaders will be able to secure more funds, unless very powerful pivotal parties predominate. In the empirical analysis we also provide results for the $(a+b)$ category, with the argument that this definition fits better with the concept of party alignment, since its computation only uses the identity of the main party of the government.

To compute these measures of alignment, we use a database provided by the Spanish Ministry of Public Administration, which gives information about the party of the mayoralty and (in the case of coalitions) the other parties in the municipal governments, following the local elections of 1991, 1995 and 1999. For the upper tier of local government, this database provides information regarding the party of the president and the composition of the assembly. Data on the party of the president of the AC and the other parties in the regional 
and national governments come from www.eleweb.com. In all cases, minority governments have been considered as coalitions. The party of the president or the mayor has been considered the Leader and the other parties belonging to the coalition, the Partners.

Our alignment measures have some properties that make them quite appropriate for the empirical analysis we wish to perform. First of all, for each of the upper layers of government and in each term of office, a large share of municipalities are unaligned. This share goes from a minimum of $24.1 \%$ for the Regional government in the third term to $57.0 \%$ for the Central government during the same term (2000-03). Aligned governments are concentrated in the $(a)$ and $(b)$ categories. Secondly, a large share of municipalities changed alignment status from one term of office to the next. The share of municipalities which changed their alignment status with the Central, Regional and Upper-local layers from 1994-95 to 1998-99, were $70.7 \%, 69 \%$ and 59.6\%, respectively. These shares were around $45 \%$ in all three cases for the transition from 1998-99 to 2002-03.

Measuring 'cut-point' density. The theoretical model suggests that the equations should include a measure of the 'cut-point density', $\phi_{j}$, or proportion of 'swing voters'. To make this variable operative we need to decide first which electoral data (Central, Regional or Municipal) are to be used to compute it. We decided to use only voting data from the last municipal elections. There are several arguments that justify this decision. Firstly, it is not advisable to include a separate measure for each of the elections, since the three would be highly correlated ${ }^{12}$. Secondly, one of the grantor governments (Upper-local) has a vested interest in these elections since its representatives are elected indirectly using the municipal voting results (see section 3.1). Thirdly, our grants variable is an average of the grants received by a municipality two years prior to municipal elections, when the vested interest of the parties will be to win the coming elections.

Most of the papers in the literature use the electoral margin of the party (i.e., vote share less 50\%, in absolute value) at the last election as a proxy for $\phi_{j}$ (Case, 2001, and Strömberg, 2001, Dasgupta et al. 2004, and Kehmani, 2003) ${ }^{13}$. However, the electoral margin may be a

\footnotetext{
${ }^{12}$ For example, the correlation coefficient between the vote share of the socialist party (PSOE) at the General and Regional elections (using the data of the Regional election prior to the General one) at the provincial level is 0.92. The correlation between the General and Municipal elections is 0.81 and the correlation between the Regional and Municipal elections is 0.83 .

${ }^{13}$ Other papers use more sophisticated measures. For example, Johansson (2003) and Dahlberg and Johansson (2004) estimate a vote density function for each municipality and then compute the 'cutpoint' density. The data requirements of this procedure make it not useful in our case.
} 
misleading measure in the case of more than two parties. When none of these parties wins a majority of the votes in the municipal election, winning or losing office and taking the best posts (i.e., the mayoralty and the greatest number of councillors) depend crucially on the probability of being the leader, or formateur, of the coalition. The party winning a larger share of votes is generally able to carry out this task. This is true in our sample, since the most voted party holds the mayoralty in the vast majority of cases ${ }^{14}$. In this case, therefore, the relevant electoral margin should be computed as the difference (in absolute value) between the vote share of the party in government and the vote share of the next party, having either more or fewer votes (Jonston et al., 1999). This is precisely the variable we include in the equation.

Control variables. We include some variables that measure the marginal valuation of spending $b_{j}$ (see Table 2 for definitions, data sources and descriptive statistics). Firstly, we control for the population size of the municipality. In Spain, current grants are clearly biased against small municipalities (Solé-Ollé and Bosch, 2005) and capital grants are biased against big municipalities. There are several explanations for this pattern. It may be that small municipalities find it harder to finance infrastructure projects either with current savings or through access to the credit market. It may also be that the upper layers are paternalistic toward small municipalities, allocating project grants that must be supervised by the grantor, instead of unconditional current grants. We expect, therefore, that per capita grants will decrease as population size increases. Secondly, we control for the land area of the municipality to account for the increasing expenditure needs generated by urban sprawl. We expect this variable to have a positive effect on the amount of grants. Assessed property values are included to account for the fiscal capacity of the municipality since, in some cases, the grantor use equalization criteria when allocating grants. The property tax rate is included because sometimes the grantor gives more monies to the municipalities which make a higher fiscal effort fiscal effort. We expect that, once we control for tax capacity, grants should be higher in municipalities with higher tax rates. Finally, we include the ratio between debt burden and current revenues. There may be two different factors at work here. On the one

\footnotetext{
${ }^{14}$ Of course, we can find examples of Spanish municipalities where the mayoralty is taken by a pivotal party, or even where two parties with similar vote shares agree to alternate the mayoralty (the two first years of the term for one party and the last two for the other). However, these cases represent a rather small share and can be safely disregarded in the empirical analysis.
} 
hand, grantors may want to give more money to more indebted municipalities, providing some sort of bailout (Wildasin, 2004). But on the other hand, most of the grants allocated are project grants funded only partially by the grantor. Therefore, a municipality with a high level of debt may also find it difficult to obtain funds to pay for its share of the cost.

Table 2:

Definitions of the variables, Descriptive Statistics and Data sources

\begin{tabular}{|c|c|c|c|}
\hline & Definition & $\begin{array}{c}\text { Mean } \\
\text { (Stand. dev.) }\end{array}$ & Source \\
\hline Central grants & $\begin{array}{l}\text { Capital grants from the Central } \\
\text { government per capita (item } 7.2 \text { of the } \\
\text { revenue budget) }\end{array}$ & $\begin{array}{c}16.050 \\
(35.933)\end{array}$ & \multirow{4}{*}{$\begin{array}{c}\text { Ministry of Economics } \\
\text { and Finance }\end{array}$} \\
\hline Regional grants & $\begin{array}{l}\text { Capital grants from the Regional } \\
\text { government (AC) per capita (item } 7.5 \\
\text { of the revenue budget) }\end{array}$ & $\begin{array}{c}48.792 \\
(64.958)\end{array}$ & \\
\hline Upper-local grants & $\begin{array}{l}\text { Capital grants from Upper-local } \\
\text { governments per capita (item } 7.6 .1 \text { of } \\
\text { the revenue budget) }\end{array}$ & $\begin{array}{c}22.728 \\
(34.969)\end{array}$ & \\
\hline Debt burden & $\begin{array}{l}\text { Debt service (capital, item } 9 \text { of the } \\
\text { spending budget, + interest, item } 3 \text { ) as } \\
\text { a share of current revenues }\end{array}$ & $\begin{array}{c}0.241 \\
(0.844)\end{array}$ & \\
\hline Margin & $\begin{array}{l}\text { Vote share of the party in government } \\
\text { - vote share second party, in absolute } \\
\text { value }\end{array}$ & $\begin{array}{c}0.089 \\
(0.072)\end{array}$ & $\begin{array}{l}\text { Ministry of Interior \& } \\
\text { Ministry of Public } \\
\text { Administration }\end{array}$ \\
\hline Population & Population & $\begin{array}{c}28,834 \\
(129,826)\end{array}$ & $\begin{array}{l}\text { National Institute of } \\
\text { Statistics (INE) }\end{array}$ \\
\hline Land area & $\begin{array}{l}\text { Urban land area per capita, including } \\
\text { both built-up area and unbuilt land } \\
\text { plots }\end{array}$ & $\begin{array}{c}333.765 \\
(388.173)\end{array}$ & \multirow{3}{*}{$\begin{array}{c}\text { Central Land } \\
\text { Management Registry } \\
\text { (Centro de Gestión } \\
\text { Catastraly } \\
\text { Cooperación } \\
\text { Tributaria) }\end{array}$} \\
\hline Property value/pop. & Assessed property value per capita & $\begin{array}{c}17,975 \\
(15,160)\end{array}$ & \\
\hline Property tax rate & $\begin{array}{l}\text { Nominal property tax rate (IBI), \% of } \\
\text { assessed property value }\end{array}$ & $\begin{array}{l}0.585) \\
(0.172)\end{array}$ & \\
\hline
\end{tabular}

\subsection{Results}

Single party + Leader alignment. Tables 3 and 4 present the results when using the Single party + Leader alignment dummy (categories $a+b$ ). Table 3 presents the results of the first two estimation procedures (i.e., (i) Cross-section and (ii) Time differences-in-differences) while Table 4 presents the results of the last two procedures (i.e., (iii) Grantor differences-indifferences and (iv) Triple differences). In all cases, a full set of provincial dummies (crosssectional methods (i) and (iii)) or term-provincial dummies (panel methods (ii) and (iv)) have been included; at the bottom of the table we include a test showing that they are significant. The explanatory performance of the equations is reasonable, with an adjusted $\mathrm{R}^{2}$ between 0.3 and 0.4 in the cross-section cases and around 0.2 in the panel cases. In all cases, the full set of variables is statistically significant. 
Table 3:

Effects of Single party + Leader alignment $(a+b)$ on grants allocated to municipalities. Cross-section and Time differences-in-differences estimation.

\begin{tabular}{|c|c|c|c|c|c|c|}
\hline & \multicolumn{3}{|c|}{ (i) Cross-section } & \multicolumn{3}{|c|}{ (ii) Time differences-in-differences } \\
\hline & Central & Regional & Upper-local & Central & Regional & Upper-local \\
\hline $\begin{array}{l}\text { Single party }+ \text { Leader } \\
\text { alignment }(a+b)\end{array}$ & $\begin{array}{c}4.430 \\
(1.544)\end{array}$ & $\begin{array}{l}13.937 \\
(5.854)^{* *}\end{array}$ & ${ }^{6.745}{ }^{* * 982)^{* *}}$ & $\begin{array}{l}6.418 \\
(2.439)^{* *}\end{array}$ & $\begin{array}{l}22.994 \\
(1.977)^{*}\end{array}$ & $\begin{array}{l}7.898 \\
(3.277)^{* *}\end{array}$ \\
\hline Margin & $(-4.358)^{* *}$ & $\begin{array}{l}-0.210 \\
(-1.288)\end{array}$ & $\begin{array}{c}-0.152 \\
(-1.563)\end{array}$ & $\begin{array}{l}-0.187 \\
(-1.293)\end{array}$ & $\begin{array}{l}-0.176 \\
(-1.239)\end{array}$ & $\begin{array}{c}-0.171 \\
(-1.398)\end{array}$ \\
\hline Population (x $10^{-6}$ ) & $\begin{array}{c}-0.001 \\
(-0.385)\end{array}$ & $\left.{ }^{-0.015}+3.727\right)^{* *}$ & ${ }^{-0.017}(-7.237)^{\text {** }}$ & $\begin{array}{c}-0.004 \\
(-3.068)^{* *}\end{array}$ & $\left.{ }^{-0.008}{ }^{* * 670}\right)^{*}$ & $(-3.275)^{* *}$ \\
\hline Land area/Pop. & $\begin{array}{l}-0.002 \\
(-2.907)^{* *}\end{array}$ & $\begin{array}{c}0.015 \\
(6.847)^{\text {** }}\end{array}$ & $\begin{array}{c}0.089 \\
(5.073)^{* *}\end{array}$ & $\begin{array}{c}-0.001 \\
(-1.250)\end{array}$ & $\begin{array}{c}0.009 \\
(5.351)^{* *}\end{array}$ & ${ }^{0.017}{ }^{(4.321)^{* *}}$ \\
\hline 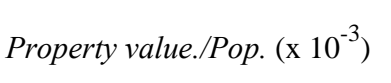 & $\begin{array}{c}-0.049 \\
(-1.786)^{*}\end{array}$ & $\begin{array}{c}-0.187 \\
(-2.495)\end{array}$ & $(-6.382)^{* *}$ & $\begin{array}{c}-0.033 \\
(-1.983)^{*}\end{array}$ & $\begin{array}{c}-0.245 \\
(-6.207)^{* *}\end{array}$ & $\begin{array}{l}-0.291 \\
(-2298)^{* *}\end{array}$ \\
\hline Property tax rate $\left(\mathrm{x} 10^{-2}\right)$ & ${ }^{0.091}{ }^{* * 019)^{* *}}$ & ${ }^{0.120}{ }^{* * 673)^{* *}}$ & ${ }^{0.183}{ }^{* *}$ & $\begin{array}{l}0.074 \\
(3.961)^{* *}\end{array}$ & ${ }^{0.115}{ }^{* .663)^{* *}}$ & ${ }^{0.367}{ }^{* * 567)^{* *}}$ \\
\hline Debt charges/Revenue & $\begin{array}{c}-0.050 \\
(-0.765)\end{array}$ & $\begin{array}{c}-0.126 \\
(-1.104)\end{array}$ & ${ }^{-0.117}(-1.694)^{*}$ & $\begin{array}{l}-0.069 \\
(-1.423)\end{array}$ & $\begin{array}{c}-0.126 \\
(-1.104)\end{array}$ & $\begin{array}{c}-0.105 \\
(-1.009)\end{array}$ \\
\hline $\operatorname{Adj} R^{2}$ & $0.435_{* *}$ & $0.398_{* *}$ & 0.301 & $0.191_{* *}$ & 0.199 & 0.165 \\
\hline F-est. (zero slopes) & $19.523^{* *}$ & $16.333^{* *}$ & $8.013^{* *}$ & $4.472^{* *}$ & $4.519^{* *}$ & $4.120^{* *}$ \\
\hline$F$-est. $(\ell$ or $\ell \times t$ dummies $)$ & $12.156^{* *}$ & $12.489^{* *}$ & $7.190^{* *}$ & $9.778^{* *}$ & $10.001^{* *}$ & $8.918^{* *}$ \\
\hline No Obs. & 1,738 & 1,738 & 1,540 & 1,738 & 1,738 & 1,540 \\
\hline
\end{tabular}

Notes: (1) $t$ statistics are shown in brackets; (2) *\&**=significantly different from zero at the $90 \%$ and $95 \%$ levels; (3) Provincial dummies included in the Cross-section equations, and Time $x$ provincial dummies included in Time differencesin-differences equations; (4) Cross-section estimation uses the average of periods 1994-95, 1998-99 and 2002-03.

Table 4:

Effects of Single party + Leader alignment $(a+b)$ on grants allocated to municipalities. Grantor differences-in-differences and Triple-differences estimation.

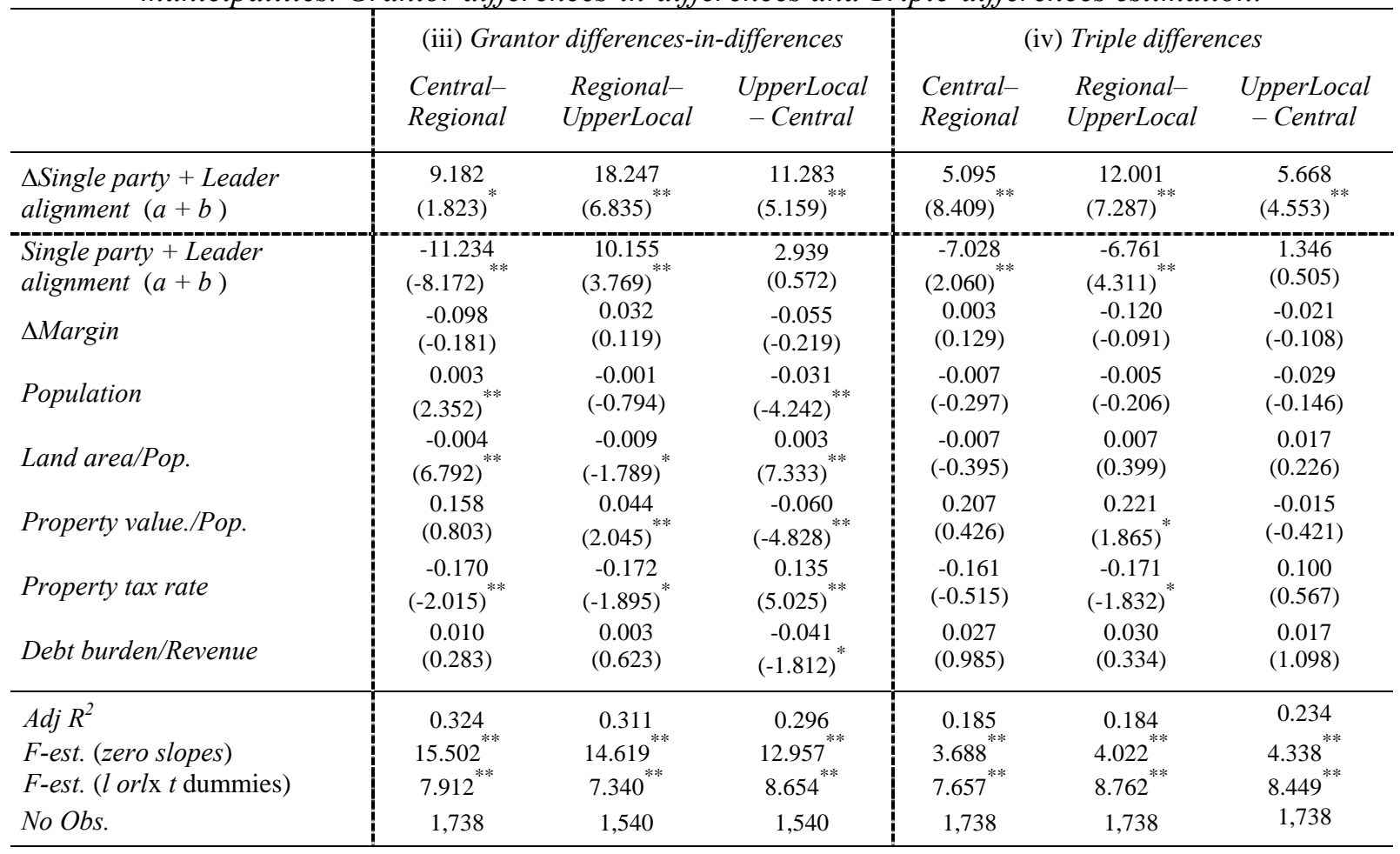

Notes: (1) $t$ statistics are shown in brackets; (2) *\&**=significantly different from zero at the $90 \%$, 95\% and 99\% levels; (3) Provincial dummies included in the Grantor differences-in-differences equations, and Time x provincial dummies included in the triple-differences equations; (4) Grantor differences-in-differences estimation uses the average of periods 1994-95, 1998-99 and 2002-03. (5) $\Delta$ Single party + Leader alignment $(a+b)$ identifies the effect of alignment on the grants received from the firstnamed grantor (i.e. Central government in the first column). (6) Single party + Leader alignment $(a+b)$ identifies the differences between coefficients (i.e. in the first column, the alignment effect vis-à-vis the Central government less the alignment effect vis-à-vis the Regional one) 
The results obtained suggest that partisan alignment between a municipality and a grantor government has a statistically significant impact on the grants allocated by the grantor to the municipality. This conclusion does not actually depend on the increasing robustness checks which are imposed when going from method (i) to methods (ii), (iii) and (iv). Alignment has a statistically significant effect at the 95\% level in all cases, with the exception of the Central government case in methods (i) Cross-section, where the coefficient is not statistically significant, and (iii) Grantor differences-in-differences, where the coefficient is statistically significant at the $90 \%$ level when comparing the Central and the Regional governments. In method (ii) Time differences-in-differences, this coefficient is statistically significant at the 90\% level for the Regional government.

There are two regularities in the results that are worth mentioning. First of all, the alignment coefficient of the Regional government is higher than those of the other layers in all cases. This result may be due to the fact that total grants distributed by Regional governments are much higher than those distributed by Central or Upper-local ones. Of course, it may also be due to a differing ability to control for other influences in each of the three cases. However, this result also holds in methods (iii) and (iv) where we allow for a different alignment coefficient for each layer while controlling for municipality-specific shocks which are common to all the grantors. In these two cases, the coefficient on $\Delta$ Single party + Leader identifies the effect of alignment on the grants received from the first-named grantor (i.e., the Central government in the first column of Table 4), while the coefficient on Single party + Leader identifies the difference between coefficients (i.e., in the first column of Table 4, the alignment effect vis-à-vis the Central government less the alignment effect vis-à-vis the Regional one). This second coefficient is negative in three regressions (i.e., the Regional government gives 11 and 7 euros more per capita to aligned municipalities than the Central government, and 10 and 7 euros more than the Upper-local one). The Central and Upper-local governments give the same amount of grants to aligned municipalities. This is to be expected, since the amount of resources at these two layers differs little. These results suggest that it is necessary to augment methods (iii) and (iv) using the full set of controls. The results without these controls are qualitatively similar (alignment coefficients are still positive and significant) but different in magnitude. 
Secondly, the coefficients obtained with methods (i) and (iv) are lower than those obtained with methods (ii) and (iii). Putting aside the results obtained with method (i), which should be the least reliable, this means that the use of method (iv) Triple differences has some influence on the estimated magnitude of the alignment effect. However, even when using the estimates coming from this method, the alignment effect appears to be sizeable. The results show that a municipality aligned with Central, Regional and Upper-local grantors will receive additional grants of 5.1, 12 and 5.7 euros per capita, respectively. These amounts represent 31.9\%, 24.9\% and 25.02\%, respectively, of the average per capita grants distributed by these layers of government.

To conclude this section, we comment on the results for the control variables. Firstly, when using methods (i) and (ii), the electoral margin variable has the expected negative sign but it is not statistically significant at conventional levels in the vast majority of cases. This variable is statistically significant only in the case of the Central government and when using method (i) Cross-section, which is the least reliable. The point estimate implies that a $10 \%$ reduction in the electoral margin with respect to the next party implies an increase in grants of 3.66 euros (22.9\% of the average grants received from the Central government). The coefficient estimates for the other layers of government are lower, but are not discussed here because the higher standard errors make them unreliable. The coefficient of the margin is zero when using methods (iii) and (iv) meaning that 'cut-point' density has a similar effect on grants allocated by all layers of government. The inability to obtain significant negative effects for the margin variable is a little disappointing, but it is in accordance with the literature (see, e.g.; Kehmani, 2003; and Rodden and Wilkinson, 2004). There may be various reasons for this. Firstly, the perceived margin may have shifted since the previous election; more sophisticated methods of calculation (see, e.g., Dahlberg and Johansson, 2004) might solve this problem. Secondly, the theoretical model posited here may not be the only one possible and other theories may lead to different relationships between margin and grants. For instance, as Cox and McCubbins (1986) suggest, if politicians are risk averse, they will allocate more resources to safe districts than to marginal ones, and more funds to marginal districts than to already lost ones. To account for this possibility, we reestimate our equations by including interactions between the margin variable with a set of dummies identifying safe and marginal municipalities. We define a 'safe' municipality as one with a positive margin 
greater than $15 \%$ (sample average + one standard deviation), a 'marginal' municipality as one with a margin (positive or negative) lower than 15\% (in absolute value), and an 'already lost' municipality as one with a negative margin lower than -15\%. Admittedly, these thresholds are rather arbitrary, but they have been selected after some trials as the ones providing the best fit. The results (not reported but available upon request) confirm our expectations. For Regional and Upper-local governments, the margin has a negative slope only for 'already lost' municipalities, the slope is zero for 'marginal' municipalities, and it is positive for 'safe' municipalities, although the coefficients are imprecisely estimated. Thus, the grants-margin function seems to be asymmetric, with a lower margin increasing grants when negative and reducing them when positive. For the Central government, however, the grants-margin function has the traditional U-inverted shape. But the most important aspect for our purposes is that this new way to specify the 'cut-point' density variable does not qualitatively change the results regarding the alignment status dummies.

In addition, the results regarding the remaining control variables are also consistent with expectations. When using methods (i) and (ii), we find that more populated municipalities receive lower per capita grants. The population coefficient is negative and statistically significant for the three grantor governments, but the effect is lower in the case of the Central government. Grants also grow with the urban land area of a municipality, except in the case of the Central government. The three upper-layer governments also allocate more grants to municipalities with low fiscal capacity (low assessed property values), although the coefficient of this variable is much lower in the case of the Central government. A higher fiscal effort (high property tax rate) also obtains more grants from the three grantor governments, but the effect is much higher in the case of Upper-local grants. Finally, the effect of the debt burden is negative in all the cases, but it is statistically significant only in one case. Most of these variables are not statistically significant when using the (iii) and (iv) methods. In some cases only, the coefficients identify significant differences in the weight given by the different grantors to each variable. For example, the results suggest that an Upper-local grantor gives more weight to the fiscal capacity indicator than a Regional one, and that a Regional grantor gives more weight to that variable than a Central grantor.

Full set of alignment categories. Tables 5 and 6 present the results using the full set of alignment categories ( $a$ to $d$ ). These tables are organized in the same way as those discussed 
before. The only two differences are that four alignment dummies appear instead of one, and that the results regarding the control variables are not shown so as to save space. In the case of the $a$ dummy (i.e. party alignment between two single parties), the results are more or less the same as before. In this case, all the coefficients are statistically significant at 95\%, with the exception of the Central government case in method (i) Cross-section, where the coefficient is significant at the $90 \%$ level. The results are similar in the case of the $b$ dummy (i.e. alignment when the party is the leader of a coalition in one or both of the layers). The coefficient is always statistically significant at 95\% when using grantor differences methods (iii) and (iv). The effects of the $c$ dummy (i.e. alignment between an upper-layer single-party or leader government and a municipal coalition partner) are always positive but only statistically significant at $90 \%$ in two cases (Central and Upper-layer in method (ii)). In the case of the $d$ dummy (i.e. party alignment between an upper-layer partner and a municipal single-party or leader government), the coefficient is statistically significant (although sometimes at the $90 \%$ level) in most cases (the exceptions are the Regional case in method (ii) and the Central case in method (iii)).

Table 5:

Effects of alignment ( $a$ to d) on grants allocated to municipalities. Cross-section and Time differences-in-differences estimation.

\begin{tabular}{|c|c|c|c|c|c|c|}
\hline & \multicolumn{3}{|c|}{ (i) Cross-section } & \multicolumn{3}{|c|}{ (ii) Time differences-in-differences } \\
\hline & Central & Regional & Upper-local & Central & Regional & Upper-local \\
\hline Single party $(a)$ & $\begin{array}{c}7.039 \\
(1.878)\end{array}{ }^{*}$ & $\begin{array}{c}16.773 \\
(5.075)^{\text {** }}\end{array}$ & $\begin{array}{c}12.406 \\
(6.007)^{* *}\end{array}$ & $\begin{array}{c}8.476 \\
(2.440)\end{array}$ & $\begin{array}{c}23.198 \\
(2.548)\end{array}$ & $\begin{array}{c}12.274 \\
(4.269)^{* *}\end{array}$ \\
\hline Leader $(b)$ & $\begin{array}{c}2.489 \\
(0.671)\end{array}$ & $\begin{array}{c}15.177 \\
(5.054)^{* *}\end{array}$ & $\begin{array}{c}1.943 \\
(0.904)\end{array}$ & $\begin{array}{c}7.351 \\
(2.343)^{* *}\end{array}$ & $\begin{array}{l}13.100 \\
(0.911)\end{array}$ & ${ }^{7.351}{ }^{* 3.343)^{* *}}$ \\
\hline Municipal partner $(c)$ & $\begin{array}{c}1.588 \\
(0.800)\end{array}$ & $\begin{array}{c}7.455 \\
(0.684)\end{array}$ & $\begin{array}{c}2.467 \\
(0.508)\end{array}$ & $\begin{array}{c}4.508 \\
(1.917)\end{array}$ & $\begin{array}{l}13.473 \\
(0.992)\end{array}$ & $\begin{array}{c}4.786 \\
(1.900)\end{array}$ \\
\hline Upper-layer partner $(d)$ & $\begin{array}{l}13.223 \\
(2.342)^{* *}\end{array}$ & $\begin{array}{l}35.646 \\
(4.152)^{* *}\end{array}$ & $\begin{array}{c}7.849 \\
(1.872)^{*}\end{array}$ & $\begin{array}{c}4.554 \\
(1.950)\end{array}$ & $\begin{array}{l}14.491 \\
(1.127)\end{array}$ & $\begin{array}{c}4.635 \\
(1.948)\end{array}$ \\
\hline $\operatorname{Adj} R^{2}$ & $0.420 *$ & 0.399 & 0.310 & 0.192 & 0.199 & 0.169 \\
\hline F-est. (zero slopes) & $18.663^{* *}$ & $14.455^{* *}$ & $8.038^{* *}$ & $4.413^{* *}$ & $4.455^{* *}$ & $4.141_{* *}^{* *}$ \\
\hline$F$-est. (l orlx $t$ dummies) & $11.781^{* *}$ & $10.219^{* *}$ & $7.549^{* *}$ & $9.975^{* *}$ & $10.219^{* *}$ & $9.093^{* *}$ \\
\hline No Obs. & 1,738 & 1,738 & 1,540 & 1,738 & 1,738 & 1,540 \\
\hline
\end{tabular}

Notes: (1) See Table 3; (2) Same controls as in Table 3. 
Table 6:

Grantor differences-in-differences and Triple-differences estimation.

\begin{tabular}{|c|c|c|c|c|c|c|}
\hline & \multicolumn{3}{|c|}{ (iii) Grantor differences-in-differences } & \multicolumn{3}{|c|}{ (iv) Triple differences } \\
\hline & $\begin{array}{l}\text { Central- } \\
\text { Regional }\end{array}$ & $\begin{array}{l}\text { Regional- } \\
\text { UpperLocal }\end{array}$ & $\begin{array}{c}\text { UpperLocal } \\
\text { - Central }\end{array}$ & $\begin{array}{l}\text { Central- } \\
\text { Regional }\end{array}$ & $\begin{array}{l}\text { Regional- } \\
\text { UpperLocal }\end{array}$ & $\begin{array}{c}\text { UpperLocal } \\
\text { - Central }\end{array}$ \\
\hline$\Delta$ Single party $(a)$ & $\begin{array}{c}13.851 \\
(7.597)^{* *}\end{array}$ & $\begin{array}{c}24.671 \\
(4.909)^{* *}\end{array}$ & $\begin{array}{c}14.638 \\
(5.238)^{* *}\end{array}$ & $\begin{array}{c}7.314 \\
(6.300)^{* *}\end{array}$ & $\begin{array}{c}18.314 \\
(8.321)^{* *}\end{array}$ & $\begin{array}{c}10.661 \\
(4.487)^{* *}\end{array}$ \\
\hline$\Delta$ Leader $(b)$ & $\begin{array}{c}6.177 \\
(2.786)^{* *}\end{array}$ & $\begin{array}{c}17.139 \\
(4.835)^{* *}\end{array}$ & $\begin{array}{c}7.148 \\
(2.998)^{* *}\end{array}$ & $\begin{array}{c}4.211 \\
(7.423)^{* *}\end{array}$ & $\begin{array}{c}12.445 \\
(7.211)^{* *}\end{array}$ & $\begin{array}{c}5.510 \\
(2.684)^{* *}\end{array}$ \\
\hline$\Delta$ Municipal partner $(c)$ & $\begin{array}{c}1.219 \\
(0.654)\end{array}$ & $\begin{array}{c}3.896 \\
(1.217)\end{array}$ & $\begin{array}{c}1.610 \\
(0.877)\end{array}$ & $\begin{array}{c}2.334 \\
(1.356)\end{array}$ & $\begin{array}{c}4.566 \\
(0.899)\end{array}$ & $\begin{array}{c}2.251 \\
(1.161)\end{array}$ \\
\hline$\Delta$ Upper-layer partner $(d)$ & $\begin{array}{l}11.678 \\
(1.511)\end{array}$ & $\begin{array}{c}13.782 \\
(3.151)^{* *}\end{array}$ & $\begin{array}{c}16.517 \\
(3.274)^{* *}\end{array}$ & $\begin{array}{c}5.443 \\
(1.822)^{*}\end{array}$ & $\begin{array}{c}15.191 \\
(3.944)^{* *}\end{array}$ & $\begin{array}{c}7.393 \\
(3.131)^{* *}\end{array}$ \\
\hline $\operatorname{Adj} R^{2}$ & 0.339 & 0.322 & 0.281 & 0.199 & 0.201 & 0.242 \\
\hline F-est. (zero slopes) & 14.832 & $14.026^{* *}$ & $12.308^{* *}$ & $3.877^{* *}$ & $3.877^{* *}$ & $3.380^{* *}$ \\
\hline F-est. (l orlx $t$ dummies) & 9.278 & $9.718^{* *}$ & $8.765^{* *}$ & $9.352^{* *}$ & $9.933^{* *}$ & $8.468^{* *}$ \\
\hline No Obs. & 1,738 & 1,540 & 1,540 & 1,738 & 1,540 & 1,540 \\
\hline
\end{tabular}

Notes: (1) See Table 4; (2) Same controls as in Table 4.

Therefore, we can conclude that there is strong evidence that upper-layer governments allocate more grants when a municipality is aligned, in the sense that both layers are controlled by the same party and that this party is either the single party in government or the leader of a coalition. There is no evidence that partners at municipal coalitions receive more grants, with the (iv) method clearly rejecting this proposition. There is evidence that partners in upper-layer coalitions are able to secure more grants for their municipalities. In this case, the coefficients obtained with the Triple-differences method are statistically significant. Using these results, the coefficients can be expressed as a percentage of the grants distributed by each grantor government. The results of this calculation show that, in the case of Single-party alignment $(a)$, the increase in grants due to alignment is $45.6 \%, 37.3 \%$ and $47.5 \%$ for the Central, Regional and Upper-local governments, respectively. In the case of Leader alignment $(b)$, these numbers are $26.2 \%, 25.39 \%$ and $24.7 \%$, respectively. The results for the Upper-layer partner case $(d)$ show increases in grants of $34.0 \%, 31.0 \%$ and $33.1 \%$. In any case, these results are in line with expectations: the alignment effect is stronger in singleparty governments but it is also present in the other cases, with the exception of Municipal partner alignment. Upper-layer partner alignment effects are not stronger than Single-party effects but are at least as strong as Leader alignment effects. Recalling that our Upper-layer partners include both pivotal parties and weaker partners, our estimates should be taken as a floor for the effect of pivotal parties, which may be even higher. In future work, we will try to 
disentangle both categories to be able to obtain more precise estimates of the pivotal-party effect.

\section{Conclusion}

In this paper we have tested the hypothesis that political alignment affects the distribution of grants among municipalities. We have developed a simple electoral competition model between parties controlling different layers, which suggests that: (i) a given grantor government gives more monies to aligned municipalities, and (ii) a given municipality receives more monies from the grantor(s) with which it is aligned. These two propositions form the basis of the empirical procedures we have used to test the alignment hypothesis. Our database has provided information on grants received by nearly 900 Spanish local governments during the period 1993-2003 from three upper-tier governments (i.e., Central, Regional and Upper-local) and allowed us to use several alternative estimation procedures. The first proposition has been tested with a cross-section estimation for the average of the period. However, since three elections were held at each tier during this period, we have enough within-municipality variation in partisan alignment to provide differences-in-differences estimates of the effects of alignment on the amount of grants coming from each source; this is the procedure used to test the second proposition. In addition the availability of panel data has allowed us to use a triple-differences estimator, which consists of estimating the effects of changing alignment status on the change in grants coming from aligned grantors relative to the change in grants coming from unaligned ones.

The results suggest that partisan alignment has a sizeable effect on the amount of grants received by municipalities. The effect is much stronger when the aligned governments are single-party governments at both layers. There is also a significant effect when the party at one or both layers is the leader of a coalition, and when a single party or a party leading a coalition at the municipal level is also partner of a coalition at the upper level. However, parties which are mere partners at the municipal level do not seem to get more grants from upper tiers of governments controlled by the same party. The size of the alignment effect is also notable; in the single-party case, aligned municipalities receive over $40 \%$ more grants than unaligned ones. Moreover, since it is possible for a municipality to become aligned/ unaligned with all the upper-layer grantors, there will be some municipalities that receive an 
overall amount of grants $40 \%$ higher than others. In other cases, however, alignment with one layer will offset unalignment with the other.

These results pose new questions for the researcher. For instance, if voters are rational, they may choose at local elections to vote for the party in charge at the upper layer in order to avoid becoming unaligned, thus protecting grant monies. In this scenario, a party winning office at the general and regional elections (only when they are held prior to municipal ones) would see its vote share increase at the municipal elections. The testing of this hypothesis will form part of our future work.

\section{References:}

Ansolabehere, S. and J.Snyder (2004): "Voting weights and formateur advantages in the formation of coalition governments." American Journal of Political Science.

Baron, D. and J. Ferejohn (1989): "Bargaining in legislatures”, American Political Science Review 83, 1181-1206.

Bertrand, M., Duflo, E. and Mullainathan, S. (2004): "How much should we trust differencesin-differences estimates?”, Quarterly Journal of Economics 119, 249-275

Buchanan, J.M. (1950): "Federalism and fiscal equity ", American Economic Review 40 , 124-138.

Case, A. (2001): "Election goals and income redistribution: recent evidence from Albania." European Economic Review 45, 405-23.

Castells, A. and Solé-Ollé,, A. (2005): "The regional allocation of infrastructure investment: The role of equity, efficiency and political factors”, European Economic Review, 49 (5), 1165-1205.

Colomer, J.M. (1995): “España y Portugal”. In J.M. Colomer (ed.), La política en Europa: introducción a las instituciones de quince países, Barcelona, Ariel.

Cox, G., and M. McCubbins (1986): "Electoral politics as a redistributive game." The Journal of Politics 48, 370-89.

Dahlberg, M. and E. Johansson (2002): "On the Vote-Purchasing Behavior of Incumbent Governments," American Political Science Review 96, 27-47.

Dahlby, B. and Wilson, L. (1994): "Fiscal capacity, tax effort, and optimal equalization grants," Canadian Journal of Economics 337, 657-672.

Dasgupta, S., A. Dhillon and B. Dutta (2004): "Electoral Goals and Centre-State Transfers in India," unpublished paper, University of Warwick.

Dixit, A., and J. Londregan (1998): "Fiscal federalism and redistributive politics.” Journal of Public Economics 68, 153-180.

Grossman, P. (1994): “A political theory of intergovernmental grants”. Public Choice 78, 295-303.

Khemani, S. (2003): "Partisan Politics and Intergovernmental Transfers in India”, Working Paper No. 3016, Development Research Group, The World Bank

Inman, R. (1988): "Federal assistance and local services in the United States: the evolution of a new federalist fiscal order.” In H. Rosen, ed., Fiscal Federalism. Chicago: University of Chicago Press.

Johansson, E. (2003): "Intergovernmental grants as a tactical instrument: empirical evidence from Swedish municipalities.” Journal of Public Economics 87, 883-915. 
Johnston, R,J., I. MacAllister, and C.J. Pattie (1999): “The funding of constituency party general election campaigns in Great Britain”, Environment and Planning C: Government and Policy 17, 391-409.

Levitt, S., and J. Snyder (1995): "Political parties and the distribution of federal outlays." American Journal of Political Science 39, 958-80.

Lindbeck, A., and J. Weibull (1987): "Balanced budget redistribution as the outcome of political competition.” Public Choice 52, 273-97.

Magre, J. (1999): L'alcalde a Catalunya. Workshop Barcelona 9, Institut de Ciències Polítiques i Socials, Barcelona.

Musgrave, R. (1959): The Theory of Public Finance: A Study in Public Economics. New York: McGraw Hill.

Oates, W. (1972): Fiscal Federalism. New York: Harcourt-Brace-Jovanovich.

Rodden, J. and Wilkinson, S. (2004): "The Shifting Political Economy of Redistribution in the Indian Federation”, MIT, mimeo, web.mit.edu/jrodden/www/ materials/ rodden. wilkinson.isnie2004.pdf

Snyder, J. (1989): "Election goals and the allocation of campaign resources." Econometrica 57, 637-60.

Solé-Ollé, A. and Bosch, N. (2005): “On the relationship between authority size and the cost of providing local services: Lessons for the design of intergovernmental transfers in Spain”, Public Finance Review 33, 343-384.

Solé-Ollé, A. (2006): "The effects of party competition on budget outcomes: empirical evidence from local governments in Spain”, Public Choice 126, 145-176.

Strömberg, D. (2002): "Optimal campaigning in presidential elections: the probability of being Florida”, Seminar Paper 706, Institute for International Economic Studies, Stockholm University.

Wildasin, D.E. (2004): “The institutions of federalism: toward an analytical approach”, National Tax Journal, 57 (2), 247-274.

Worthington, A., and B. Dollery (1998): "The political determination of intergovernmental grants in Australia.” Public Choice 94, 299-315. 


\section{CESifo Working Paper Series}

(for full list see www.cesifo-group.de)

1796 Louis Eeckhoudt, Béatrice Rey and Harris Schlesinger, A Good Sign for Multivariate Risk Taking, September 2006

1797 Dominique M. Gross and Nicolas Schmitt, Why do Low- and High-Skill Workers Migrate? Flow Evidence from France, September 2006

1798 Dan Bernhardt, Stefan Krasa and Mattias Polborn, Political Polarization and the Electoral Effects of Media Bias, September 2006

1799 Pierre Pestieau and Motohiro Sato, Estate Taxation with Both Accidental and Planned Bequests, September 2006

1800 Øystein Foros and Hans Jarle Kind, Do Slotting Allowances Harm Retail Competition?, September 2006

1801 Tobias Lindhe and Jan Södersten, The Equity Trap, the Cost of Capital and the Firm's Growth Path, September 2006

1802 Wolfgang Buchholz, Richard Cornes and Wolfgang Peters, Existence, Uniqueness and Some Comparative Statics for Ratio- and Lindahl Equilibria: New Wine in Old Bottles, September 2006

1803 Jan Schnellenbach, Lars P. Feld and Christoph Schaltegger, The Impact of Referendums on the Centralisation of Public Goods Provision: A Political Economy Approach, September 2006

1804 David-Jan Jansen and Jakob de Haan, Does ECB Communication Help in Predicting its Interest Rate Decisions?, September 2006

1805 Jerome L. Stein, United States Current Account Deficits: A Stochastic Optimal Control Analysis, September 2006

1806 Friedrich Schneider, Shadow Economies and Corruption all over the World: What do we really Know?, September 2006

1807 Joerg Lingens and Klaus Waelde, Pareto-Improving Unemployment Policies, September 2006

1808 Axel Dreher, Jan-Egbert Sturm and James Raymond Vreeland, Does Membership on the UN Security Council Influence IMF Decisions? Evidence from Panel Data, September 2006

1809 Prabir De, Regional Trade in Northeast Asia: Why do Trade Costs Matter?, September 2006 
1810 Antonis Adam and Thomas Moutos, A Politico-Economic Analysis of Minimum Wages and Wage Subsidies, September 2006

1811 Guglielmo Maria Caporale and Christoph Hanck, Cointegration Tests of PPP: Do they also Exhibit Erratic Behaviour?, September 2006

1812 Robert S. Chirinko and Hisham Foad, Noise vs. News in Equity Returns, September 2006

1813 Oliver Huelsewig, Eric Mayer and Timo Wollmershaeuser, Bank Behavior and the Cost Channel of Monetary Transmission, September 2006

1814 Michael S. Michael, Are Migration Policies that Induce Skilled (Unskilled) Migration Beneficial (Harmful) for the Host Country?, September 2006

1815 Eytan Sheshinski, Optimum Commodity Taxation in Pooling Equilibria, October 2006

1816 Gottfried Haber and Reinhard Neck, Sustainability of Austrian Public Debt: A Political Economy Perspective, October 2006

1817 Thiess Buettner, Michael Overesch, Ulrich Schreiber and Georg Wamser, The Impact of Thin-Capitalization Rules on Multinationals' Financing and Investment Decisions, October 2006

1818 Eric O’N. Fisher and Sharon L. May, Relativity in Trade Theory: Towards a Solution to the Mystery of Missing Trade, October 2006

1819 Junichi Minagawa and Thorsten Upmann, Labor Supply and the Demand for Child Care: An Intertemporal Approach, October 2006

1820 Jan K. Brueckner and Raquel Girvin, Airport Noise Regulation, Airline Service Quality, and Social Welfare, October 2006

1821 Sijbren Cnossen, Alcohol Taxation and Regulation in the European Union, October 2006

1822 Frederick van der Ploeg, Sustainable Social Spending in a Greying Economy with Stagnant Public Services: Baumol’s Cost Disease Revisited, October 2006

1823 Steven Brakman, Harry Garretsen and Charles van Marrewijk, Cross-Border Mergers \& Acquisitions: The Facts as a Guide for International Economics, October 2006

1824 J. Atsu Amegashie, A Psychological Game with Interdependent Preference Types, October 2006

1825 Kurt R. Brekke, Ingrid Koenigbauer and Odd Rune Straume, Reference Pricing of Pharmaceuticals, October 2006

1826 Sean Holly, M. Hashem Pesaran and Takashi Yamagata, A Spatio-Temporal Model of House Prices in the US, October 2006 
1827 Margarita Katsimi and Thomas Moutos, Inequality and the US Import Demand Function, October 2006

1828 Eytan Sheshinski, Longevity and Aggregate Savings, October 2006

1829 Momi Dahan and Udi Nisan, Low Take-up Rates: The Role of Information, October 2006

1830 Dieter Urban, Multilateral Investment Agreement in a Political Equilibrium, October 2006

1831 Jan Bouckaert and Hans Degryse, Opt In Versus Opt Out: A Free-Entry Analysis of Privacy Policies, October 2006

1832 Wolfram F. Richter, Taxing Human Capital Efficiently: The Double Dividend of Taxing Non-qualified Labour more Heavily than Qualified Labour, October 2006

1833 Alberto Chong and Mark Gradstein, Who's Afraid of Foreign Aid? The Donors' Perspective, October 2006

1834 Dirk Schindler, Optimal Income Taxation with a Risky Asset - The Triple Income Tax, October 2006

1835 Andy Snell and Jonathan P. Thomas, Labour Contracts, Equal Treatment and WageUnemployment Dynamics, October 2006

1836 Peter Backé and Cezary Wójcik, Catching-up and Credit Booms in Central and Eastern European EU Member States and Acceding Countries: An Interpretation within the New Neoclassical Synthesis Framework, October 2006

1837 Lars P. Feld, Justina A.V. Fischer and Gebhard Kirchgaessner, The Effect of Direct Democracy on Income Redistribution: Evidence for Switzerland, October 2006

1838 Michael Rauscher, Voluntary Emission Reductions, Social Rewards, and Environmental Policy, November 2006

1839 Vincent Vicard, Trade, Conflicts, and Political Integration: the Regional Interplays, November 2006

1840 Erkki Koskela and Mikko Puhakka, Stability and Dynamics in an Overlapping Generations Economy under Flexible Wage Negotiation and Capital Accumulation, November 2006

1841 Thiess Buettner, Michael Overesch, Ulrich Schreiber and Georg Wamser, Taxation and Capital Structure Choice - Evidence from a Panel of German Multinationals, November 2006

1842 Guglielmo Maria Caporale and Alexandros Kontonikas, The Euro and Inflation Uncertainty in the European Monetary Union, November 2006 
1843 Jan K. Brueckner and Ann G. Largey, Social Interaction and Urban Sprawl, November 2006

1844 Eytan Sheshinski, Differentiated Annuities in a Pooling Equilibrium, November 2006

1845 Marc Suhrcke and Dieter Urban, Are Cardiovascular Diseases Bad for Economic Growth?, November 2006

1846 Sam Bucovetsky and Andreas Haufler, Preferential Tax Regimes with Asymmetric Countries, November 2006

1847 Luca Anderlini, Leonardo Felli and Andrew Postlewaite, Should Courts always Enforce what Contracting Parties Write?, November 2006

1848 Katharina Sailer, Searching the eBay Marketplace, November 2006

1849 Paul De Grauwe and Pablo Rovira Kaltwasser, A Behavioral Finance Model of the Exchange Rate with Many Forecasting Rules, November 2006

1850 Doina Maria Radulescu and Michael Stimmelmayr, ACE vs. CBIT: Which is Better for Investment and Welfare?, November 2006

1851 Guglielmo Maria Caporale and Mario Cerrato, Black Market and Official Exchange Rates: Long-Run Equilibrium and Short-Run Dynamics, November 2006

1852 Luca Anderlini, Leonardo Felli and Andrew Postlewaite, Active Courts and Menu Contracts, November 2006

1853 Andreas Haufler, Alexander Klemm and Guttorm Schjelderup, Economic Integration and Redistributive Taxation: A Simple Model with Ambiguous Results, November 2006

1854 S. Brock Blomberg, Thomas DeLeire and Gregory D. Hess, The (After) Life-Cycle Theory of Religious Contributions, November 2006

1855 Albert Solé-Ollé and Pilar Sorribas-Navarro, The Effects of Partisan Alignment on the Allocation of Intergovernmental Transfers. Differences-in-Differences Estimates for Spain, November 2006 